\section{Public Health Observatories in England: recent transformations and continuing the legacy}

\author{
Os Observatórios de Saúde Pública na Inglaterra: \\ mudanças recentes e continuação do legado
}

\section{Los Observatorios de Salud Pública en Inglaterra: cambios recientes y continuacción del legado}

John Wilkinson 1,2

\section{Resumo}

Os Observatórios de Saúde Pública foram criados na Inglaterra em 2000 como instâncias auxiliares importantes para o sistema de saúde pública no país. Os observatórios constituíram uma rede, que permitiu o compartilhamento de experiências e a disseminação rápida de métodos e resultados. Essa rede cresceu até cobrir todo o Reino Unido e Irlanda, servindo como força altamente bem-sucedida em favor de mudanças, até que os observatórios foram subsumidos pela nova agência governamental de saúde pública, chamada Public Health England. O artigo descreve as lições aprendidas ao longo dos 14 anos de existência dos observatórios junto ao sistema de saúde pública da Inglaterra.

Health Systems; Knowledge Management for Health Research; Urband Health
Sistemas de Saúde; Gestão do Conhecimento para a Pesquisa em Saúde; Saúde Urbana 


\section{Introduction}

Public Health Observatories (PHOs) in England were established in 2000 following the publication of the UK Government's white paper (a statement of proposed Government policy), Saving Lives: Our Healthier Nation 1. "Saving Lives" was an ambitious document, claiming to herald a new approach to public health. It focused action in four areas with targets (Figure 1). To attain these ambitious aims, "Saving Lives" called for the creation of a regional network of public health observatories. They operated very successfully until 2013 when reorganization of the health service subsumed the observatories into a new Government agency called Public Health England. This article describes the establishment and evolution of public health observatories in England and offers some reflections on their lasting legacy. The English PHOs had a distinctly "regional focus", serving populations of between 2.6 and 8.7 million ${ }^{2}$. Although having a slightly different role, the Office for National Statistics, some would argue already served some of the functions of a national PHO, especially if some of the activities of the Department of Health were also included.

"Saving Lives" proposed an integrated approach to health improvement across Government, and the document itself was significant in that it was signed by 12 Government Ministers and the Prime Minister. The section relevant to information was as described in Figure 2.

\section{Establishment and evolution of the observatories}

\section{Context}

"Saving Lives" was a wide-ranging set of proposals on public health. As well as creating $\mathrm{PHO}$, which were referred to in a very short paragraph, this proposed legislation also established a number of other new public health initiatives. This included the Health Development Agency (HDA - now abolished), which was charged with translating policy into action. A regional structure was established to facilitate this, backed up by a strong central function. It had a strong remit to encourage evidencebased practice. But the HDA was abolished in 2005 with a number of its functions being subsumed into the National Institute for Clinical Evidence (NICE). NICE then underwent a name change to the National Institute for Health and Care Excellence, though it retained the same acronym.
It was stated that the PHOs would be linked together to form a national network of knowledge, information and surveillance in public health, and would be a major new resource for local bodies working in public health. The observatories were said to be modeled on the Liverpool Health Observatory, which had been created in 1990.

One of the important developments in the creation of PHOs in England was the creation of the Association of Public Health Observatories (APHO). Collaboration between regions of England had always been strong, and so a national structure linking these regional bodies was a very natural part of the evolution.

APHO was set up at the same time as PHOs were established. Its aim was to coordinate work between the PHOs, to avoid duplication, disseminate good practice, and to allow the principle of "doing once for all" to be applied. We had many successes as APHO, where expertise was pooled. Health profiles 3 for all local authorities and the production of single topic reports for the Chief Medical Officer were examples of outputs from this collaboration. APHO was modeled on the cancer registries association in the UK (the UKACR), and also a similar organization in France (Fédération National Observatoires Régionaux de Santé - FNORS; http:/ / www.fnors. org) which coordinates the work of the French Health Observatories.

Initially established as an England only body, the English Observatories quickly extended membership to other parts of the UK. Health profiles were borne out of similar work in Scotland, and much was learnt from our Scottish colleagues. Wales was establishing its own PHO at the same time as the English PHOs, and was very keen to do this in collaboration with the rest of the UK. The Institute of Public Health in Ireland was established in 1999 (under the 1999 "Good Friday" agreement), and the chair of APHO at the time was an advisor to establishing the allIreland observatory. That observatory, INIsPHO, was formed and became a member of APHO. Over the years all the "Celtic countries" were full members and active participants in APHO A number of pieces of joint work were undertaken. The coverage of PHOs in UK and Ireland also proved to be a great advantage in joining in European Union-funded projects.

\section{PHO functions}

"Saving Lives" had proposed some very specific functions for public health observatories; these are shown in Figure 3. 
Figure 1

Targets set out in Saving Lives: Our Healthier Nation 1.

\section{Cancer}

Reduce the death rate from cancer in people under 75 by at least a fifth - saving 100,000 lives.

\section{Coronary heart disease and stroke}

Reduce the death rate from coronary heart disease and stroke and related diseases in people under 75 by at least two fifths -

saving 200,000 lives.

\section{Accidents}

Reduce the death rate from accidents by at least a fifth and to reduce the rate of serious injury from accidents by at least a tenth saving 12,000 lives.

\section{Mental health}

Reduce the death rate from suicide and undetermined injury by at least a fifth - saving 4,000 lives

Figure 2

Section on information from Saving Lives: Our Healthier Nation 1.

INFORMATION FOR HEALTH

11.30 In order to strengthen the availability and use of information about health at local level we will ensure that there is a Public Health Observatory in each NHS region of the country. These observatories will be closely linked with universities to help bring an academic rigor to their work.

Figure 3

Proposed roles of Public Health Observatories from Saving Lives: Our Healthier Nation 1.

Roles of Public Health Observatories

- Monitor health and disease trends and highlight areas for action

- Identify gaps in health information

- Advise on methods for health and inequality impact assessment

- Draw together information from different sources to improve health

- Evaluate progress by local agencies in improving health and cutting inequality

- Look ahead to give early warning of public health problems 
Public Health Observatories were set up initially in the eight National Health Service (NHS) regions of England. Subsequently in 2004, an additional ninth observatory was created and the boundaries of the PHOs moved to those of the Government Office Regions. The decision to create regional or local observatories was made in order that they would be able to serve a defined geographical population and to relate to the people living and working in that geographical area. These local relationships were critical to their success. National organizations are often seen as "distant and remote", particularly the further that one gets from London.

PHOs were based in a number of different organizations, such as universities or government offices of the regions which existed at that time. The London Health Observatory had a variety of host organizations, and some were based in local NHS organizations. For those outside the NHS, the piecemeal nature of the funding was a problem in that host organizations were not happy for PHOs to commit resources and appoint staff on permanent contracts. This had a detrimental effect on recruitment. Subsequently an enlightened official in the Department of Health provided assurances that should PHOs be wound up, any costs of cessation would be met by the Department of Health. This was a major step forward and enabled PHOs to appoint permanent staff.

Shortly after their inception, six out of nine of the observatories took on the National Drug Treatment and Monitoring Service (a system to monitor and report on the level of drug misuse). This added a welcome new income stream to these observatories.

Observatories very quickly became organizations which were seen to be able to get things done, and were increasingly commissioned to take on additional short term funded pieces of work. In the North East PHO, in the last two years of its operation, the organization had a turnover of around £2million ( $\$ 3.39$ million), with core income amounting to around $£ 500,000(\$ 850,000)$.

In some parts of the country the synergy with cancer registries and their functions was recognised. In the South West for example, the PHO and the registry had worked as a combined operation from the beginning; in other parts of the country, increasingly when cancer registry directors left, the cancer registry function was transferred to the responsibility of the PHO.

All this was made possible by a very supportive Chief Medical Officer in England, and a supportive Department of Health. Indeed in 2010, after the first ten years of PHOs, they were described as the jewel in the crown of public health 4 .
The Chief Medical Officer, in his meetings with PHOs and the regional directors of public health, made it very clear that he wanted PHOs to be mildly irritating and to raise questions and issues which might be too uncomfortable to be raised by those closer to government. The independent role was emphasized and supported. However, this did not last, with the change of government to Conservative (more right wing) and the change of Chief Medical Officer, PHOs became to be seen as "too independent".

As well as "core functions" all PHOs had a number of specialist areas (three to four per PHO). This enabled PHOs to develop expertise in particular areas such as mental health and inequalities. It was a move that was very popular with national organizations, as it allowed these to talk to a single PHO and also one which had developed a degree of expertise in that particular field. One of the specialist areas was focused on international collaboration. Set out below are some activities which were developed in this area, which helped to establish PHOs international credentials.

\section{International collaboration}

The North East PHO led the international work of the APHO and worked closely with other PHOs who had interests in an international dimension. The London Health Observatory was particularly involved as most visitors from abroad find it easy to visit the capital city.

Observatories were very successful over the years in participating in international projects and some of these are detailed below.

\section{- ISARE - Indicators of Health in the Regions of Europe 5,6,7}

This was a series of projects funded by the European Commission (DG Sanco) starting in 2001. The project dealt with the development of health indicators at a sub-national level in Europe. It was a series of projects widely welcomed by the Commission and culminated in the publication of 265 health profiles for the regions of Europe in 2010. The project had to deal with the definition of "regions" and difficulties in using comparative data across the different countries in Europe. Additional work had to be carried out when the EU expanded from 15 to 27 countries. It is expected that this work will be repeated in 2-3 years time. It was coordinated by FNORS, the French association of health observatories, with which PHOs in the UK and Ireland had very close links over the years. 


\section{- Public Health Genomics European} Network (PHGEN)

This was an international project which examined the implications of the genetic revolution on public health in Europe. It was coordinated by the University of Maastricht in the Netherlands, and the UK was a partner in the work. PHOs contributed to thinking what the future intelligence needs to support this revolution would be. In the future, we concluded, it will be necessary not only to collect information about health and disease, but also to assemble data on the genetic composition (and therefore the risks) of the population. Some initial thoughts were published elsewhere ${ }^{8}$. A number of reports have been published and there are extremely important implications for health systems around the world.

Spreading the PHO model globally and helping build capacity

\section{- Example 1: building the global observatory movement}

PHOs in the UK and Ireland were at the forefront of the development of the global observatory movement, in the making and receiving of international visits, supporting relevant WHO work, and spreading the equity messages.

In 2005 a delegation from the UK and Ireland visited Canada at their request to advise on the development of "Health Canada" and in particular its information role. The contacts developed have been maintained and a follow-up meeting was held in Gateshead in 2009. Subsequently one senior member of staff spent a six-month secondment in Canada, contributing to the creation of a health observatory in Saskatoon, based on the English model.

\section{- Example 2: Injury Observatory for Britain and Ireland (IOBI)}

The Injury Observatory for Britain and Ireland (IOBI) is a collaborative effort, with no dedicated funding, between a number of Public Health Observatories and somekeyacademicinstitutions. Its work still continues to this date (see: http://www. injuryobservatory.net, accessed on 01/Aug/2014).

The purpose is to support those working on the prevention of injuries caused by accidents, violence or self harm, by making important and relevant information and tools available in one site, including: (i) Analyses of trend in injury deaths, hospital admissions and injury occurrence across countries and regions; and (ii) Policy support for prevention.

\section{Funding}

All the developments in "Saving Lives" were backed up with an important level of funding, named the public health development fund, which amounted to at least £96 million (\$162 million) over three years.

However, from the outset, it was made clear that the core funding made available for PHOs was to be seen as "seed" funding and that PHOs were expected to look for alternative sources of funding. Although funding was never withdrawn (until the latter years), PHOs continued to receive a level of core funding from the Department of Health. Initially this was received on an annual basis, which caused some problems for longerterm planning and resource allocation.

This additional level of funding was quickly followed up by observatories being asked to take on a regional function for hospital inpatient data (the hospital episode statistics service, HES). Again this came with an additional level of funding, which added to the security and permanence of the PHOs.

Some examples of the broader work of the Observatories

\section{- Legacy and future of the PHOs in England}

The newly elected government in England in 2010 quickly passed legislation that was to reform the public health system and bring into being a new organization called Public Health England (PHE). This subsumed much of the public health infrastructure in England, including the PHOs, but also included the eight regional cancer registries, the quality assurance reference centres from the cancer screening programmes, the services responsible for monitoring the levels of drug and alcohol misuse in the population, the Health Protection Agency, and some of the remaining regional public health infrastructure. A total of 40 different organisations eventually went into PHE, creating massive organizational change and considerable inertia while transition was taking place. After much debate the government decided that PHE would be part of the civil service. At the same time there was radical change to public health in the NHS. Public health directors and their staff were transferred from the NHS where they had been since 1974, into local authorities where it was felt they would be better placed to influence the wider determinants of health.

One of the problems was the way in which the reorganization was protracted. Because of the concerns about the NHS reorganization that 
was taking place at the same time (this had not been signaled in any manifesto) and was highly unpopular, this was all put on hold for a year "the pause". Unfortunately this led to a further attrition of staff who were not prepared to live with the uncertainty involved.

The functions of PHOs were transferred into PHE and continue there to this date. However, PHOs were effectively dismantled, as was the highly successful APHO. The remaining staff were transferred into PHE to become the Knowledge and Intelligence function, and the word "region" was dropped. Why this was the case still remains open to speculation, as at the same time, some of the other organizations going into PHE were largely unscathed and still continue to exist in PHE with their own identity.

PHOs were remarkably successful, in an NHS which is constantly being reformed in England, simply lasting 13 years was a major achievement. It is regrettable, that although much good work was undertaken that a formal evaluation was never undertaken. This is an important lesson for the future. Anticipating scrutiny, the PHOs themselves established peer review scrutiny and audit, which itself was very helpful in communicating good practice across PHOs.

There is now a strategic review being carried out into PHE. There is even some talk among senior colleagues that the loss of the observatories should be reversed as it was a mistake. The way in which observatories have developed in other parts of the world has been something of a wake up call to those in the public health system in England.

\section{Main functions and policy impact of the PHOs}

Given the proliferation of organizations calling themselves health-related observatories, we decided to attempt to clarify the roles and functions of PHOs to protect the brand. We published our views on what constituted a health observatory 9 . We concluded that the main tests of an observatory were if it carried out the following functions: (i) The primary characteristic of these observatories is that they produce and disseminate intelligence for their host area, such as on regional health development; (ii) PHOs reflect the increasing importance of cross-agency work, health inequalities and evidence-based policy making.

It of course is always difficult to quantify the benefits of an organization such as a PHO. However we set out some of the achievements of the first ten years of PHOs in a publication at the time 4 .
We also did operate in a market and competed against private sector, other parts of the NHS, and academia. We were very successful at this, which could be measured by our income.

The international profile for PHOs in England was well recognized. Our expertise was requested from all over the world.

\section{Conclusions and discussion}

So what were the main challenges we faced on transition to a new civil service organization, and the challenges and opportunities for new observatories which are developing worldwide?

\section{Challenges}

\section{- Retaining the talent developed over 10 years}

The observatories in the UK grew exponentially over their first ten years of existence and were a major force for change in public health in the UK and Ireland. Once reorganization was a possibility, many staff left and retention became a serious problem. The problem was made worse by the protracted nature of the NHS reorganization in England, which was "paused" for a year because of political concerns. Many staff were able to find alternative employment in other research organizations and health charities.

\section{- Maintaining an independent public health voice: a real challenge for PHE}

A former Chief Medical Officer in England had welcomed PHOs in being able to say things, which he was not. Many of the PHO directors had had experience of being Directors of Public Health, and were therefore very familiar with the tension between speaking out on behalf of the public's health and the need for organizational corporacy.

PHE, being part of the civil service, has the additional tension of being primarily there to support the government and ministers. Its communications divisions became much more powerful and were able to prevent the successors to PHOs from publishing any material which might be seen as contentious.

\section{- Civil service culture}

The civil service culture was a very difficult pill for many former NHS employees to swallow. The emphasis of PHE in serving ministers was difficult. Indeed a select committee report on PHE suggested that it needed to be more independent. 


\section{Opportunities}

Some of the enthusiasm and commitment which we saw in PHOs in England in the early days was inevitably lost. Giving a number of experienced and committed people a small amount of relatively unconstrained resource had reaped huge rewards. It is rewarding to see that some of the principles of the PHOs are now being replicated around the world. The opportunity which PHOs have to work between academic and service public health is an unparalleled opportunity and is a very exciting area to work in. PHE is now undertaking a strategic review which may even herald the return of PHOs.

Looking further afield, it is very encouraging to see how observatories are developing worldwide, enabling information and intelligence to be translated into public health policy. The close relationship between those working in information and those in policy areas within observatories offers a great advantage, and encourages the adoption of evidence-based decision making. The developing observatories worldwide also have the opportunity to advance in the following areas:

\section{- Further developing capacity}

One of our prime objectives in the UK was to develop skills and capacity, especially for information specialists. In the numerous reorganizations of the English NHS, although public health consultants had been relatively well protected, many of the other specialist staff such as analysts were not. Many of these working in the NHS quickly found alternative employment in other sectors, and in particular in universities and the drug industry. So it was a prime function for PHOs to develop capacity.

We developed training programs which led to accreditation of specialist status. PHOs were instrumental in bringing about consultant status for senior information specialists. Some PHOs were able to jointly organize and fund masters' programs and a number of PHOs funded PhD students. In addition, PHOs were often co-applicants for research grant funding which often included the funding of additional $\mathrm{PhD}$ students. Much of the training infrastructure remains in place and has been built on since its inception.
- Developing a community of specialists in public health intelligence with a more direct relationship with policy makers

Being in a public health observatory can encourage staff to be much more outward facing than is sometimes possible if working in an information unit as part of a larger organization. Having an effective network, has a huge multiplier effect on impact. Work being carried out in one part of the country (or in one country) is more often than not directly relevant to another part of the country (or other country). Working together reduces duplication and produces much greater clarity of the message. Information specialists can become familiar with work being carried out in other places, other countries and so the opportunities for learning and disseminating good practice become greatly enhanced.

\section{- Being relevant to local areas and to local public health}

Observatories were well placed to be able to forge close relationships with their local communities and to become known to them. In England, some were more successful than others. Our experience shows that they can be at the centre of regional public health policy, and can be heavily involved in public health training in their local areas.

Health intelligence and its usage can be a major driver of change in public health, as the PHOs in England demonstrated in their thirteen years of existence. Having a degree of independence to state uncomfortable messages is a critical role and a role that a mature democratic system should be able to cope with. It is debatable whether there has been as much profile given to public health in the media since the demise of PHOs in England. The new PHE struggles to establish its place as both authoritative and independent, albeit as part of the government civil service. PHOs are a great concept and it is hoped that the spark that has been kindled in the UK will continue to be a major contributing factor in improving public health globally. 


\section{Resumen}

Los Observatorios de Salud Pública se crearon en Inglaterra en 2000 como importantes órganos auxiliares para el sistema de salud pública en el país. Los observatorios establecieron una red, permitiendo el intercambio de experiencias y la rápida difusión de los métodos y resultados. Esta red creció hasta cubrir todo el Reino Unido e Irlanda, sirviendo como fuerza de gran éxito para el cambio, hasta que los observatorios fueron subsumidos por la nueva salud pública agencia gubernamental, la Public Health England. El artículo describe las lecciones aprendidas durante los 14 años de existencia de los observatorios en el sistema de salud pública en Inglaterra.

Sistemas de Salud; Gestión del Conocimiento para la Investigación en Salud; Salud Urbana

\section{References}

1. Department of Health. Saving lives: our healthier nation. London: The Stationery Office; 1999.

2. Office for National Statistics. Reference table: region and country profiles - key statistics tables, October 2013. http://www.ons.gov.uk/ons/regional-statistics/index.html\#tab-data-tables (accessed on 25/Oct/2014).

3. Bradford C, Hill A, Wilkinson J. English health profiles - did they do what was expected? An evaluation of health profiles 2006. Public Health 2009; 123:311-5.

4. Wilkinson JR, Ferguson B. The first ten years of public health observatories in England - and the next. Public Health 2010; 124:245-7.

5. Ochoa A, Ledésert B. Health indicators in the European regions. ISARE Project. http://www.isare. org/fichiers_isare/pdf/ISAREEn.pdf. (accessed on 28/Feb/2015).

6. Wilkinson J, Berghmans L, Imbert F, Ledésert B, Ochoa A; ISARE II Project Team. Health Indicators in the European regions - ISAREII. Eur J Public Health 2008; 18:178-83.

\section{Acknowledgments}

All former colleagues in the UK and Ireland Public Health Observatories and colleagues and friends from around the world.
7. Wilkinson JR, Berghmans L, Imbert F, Ledésert B, Ochoa A; ISARE III Project Team. Health indicators in the European regions: expanding regional comparisons to the new countries of the European Union - ISARE III. Public Health 2009; 123:490-5.

8. Wilkinson JR, Ells LJ, Pencheon D, Flowers J, Burton $\mathrm{H}$. Public health genomics: the interface with public health intelligence and the role of public health observatories. Public Health Genomics 2011; 14:35-42.

9. Hemmings J, Wilkinson JR. What is a public health observatory? J Epidemiol Community Health 2003; 57:324-6.

Submitted on 30/Jun/2014

Final version resubmitted on 27/Nov/2014 Approved on 07/Jan/2015 